\title{
PERFORMANCE ASSESSMENT OF GREEN PRACTICES IN LIMING WITH REDUCTIVE POTENTI- AL CHEMICALS FOR ENVIRONMENTAL SUSTAINABILITY
}

\section{Bahri BASARAN, Ali YORGANCIOGLU, Ersin ONEM*, Behzat Oral BITLISLI}

Ege University, Faculty of Engineering, Department of Leather Engineering, 35100, Izmir, Turkiye, e-mail:

\author{
deri@mail.ege.edu.tr
}

Received: 13.05.2019

Accepted: 13.09.2019

https://doi.org/10.24264/Ifj.19.3.2

PERFORMANCE ASSESSMENT OF GREEN PRACTICES IN LIMING WITH REDUCTIVE POTENTIAL CHEMICALS FOR ENVIRONMENTAL SUSTAINABILITY

ABSTRACT. Leather processings involved in isolation in pre-tanning stages generate large volumes of solid wastes and high strength wastewater which are major source of environmental pollution characterized by chemical oxygen demand (COD), biological oxygen demand (BOD), total dissolved solids (TDS), total suspended solids (TSS), chromium (III) and phenolics with high pH, strong odor and dark brown color. Leather industry wastewaters with high organic content and pollution load are generated from pre-tanning processes. Conventional pre-tanning process utilises chemicals which attributes to $50-60 \%$ of pollution load and alkaline effluent discharge of $70-80 \%$ toxicity. In our study, the best practices modelling and eco-compatible process shifts were the objectives for the decrement in high pollution load of large effluent portion for leather industry. Soaking, immunization and liming processes were carried out with reductive chemical additives and surfactants, fibre opening auxiliaries, enzyme based and enzyme assisted chemicals in the factories as an eco-friendly designed recipe. Studies were conducted in Bursa Leather Park, Turkey. The results revealed the advantages of time saving, cost effectivity and minimized pollution load compared to conventional process. Moreover, the designed process uses lower amount of alkaline chemicals and water, gives a very high quality pelts with open grain and yield in 50-55\% lime split output with 2.2-2.4 mm thicknesses.

KEY WORDS: leather, liming, wastewater, environment, sustainability

\section{EVALUAREA PERFORMANTEI PRACTICILOR ECOLOGICE ÎN OPERATIA DE CENUŞĂRIRE UTILIZÂND SUBSTANTE CHIMICE CU POTENTIAL DE} REDUCERE PENTRU SUSTENABILITATEA MEDIULUI

REZUMAT. Procesele individuale de prelucrare a pielii în etapele dinaintea tăbăcirii generează volume mari de deşeuri solide şi ape uzate, care reprezintă sursa majoră de poluare a mediului caracterizată prin consum chimic de oxigen (CCO), consum biologic de oxigen (CBO), total solide dizolvate (TDS), total solide în suspensie (TSS), crom(III) şi compuşi fenolici cu pH ridicat, miros puternic şi culoare maro închis. Apele uzate din industria pielăriei cu conţinut organic şi poluant ridicat sunt generate din procesele anterioare tăbăcirii. În procesul convenţional de pre-tăbăcire se folosesc substanţe chimice care reprezintă 50-60\% din cantitatea de poluanţi şi de efluenţi alcalini cu 70-80\% toxicitate. În studiul nostru, modelarea celor mai bune practici şi schimbările procesului eco-compatibile au reprezentat obiectivele pentru reducerea cantităţii ridicate de poluanţi din efluenţii care provin din industria de pielărie. Procesele de înmuiere, imunizare şi cenuşărire au fost realizate cu aditivi chimici reductivi şi tensioactivi, auxiliari pentru deschiderea fibrelor, substanţe chimice pe bază de enzime şi asistate de enzime, utilizând o reţetă ecologică. Studiile au fost efectuate în Bursa Leather Park, Turcia. Rezultatele au relevat avantajele economisirii timpului, eficiența costurilor şi încărcarea minimă a poluării în comparație cu procesul convenţional. Mai mult decât atât, procedeul conceput utilizează o cantitate mai mică de substanţe chimice alcaline şi apă, se obţin piei gelatină de înaltă calitate, cu fibre deschise şi cu un randament de 50$55 \%$ piei şpalt cenuşărite cu grosimi de 2,2-2,4 mm.

CUVINTE CHEIE: piele, cenuşărire, ape uzate, mediu, durabilitate

\section{ÉVALUATION DES PERFORMANCES DES PRATIQUES ÉCOLOGIQUES DANS L'OPÉRATION DE PELANAGE UTILISANT DES PRODUITS} CHIMIQUES À POTENTIEL D'OXYDORÉDUCTION POUR LA DURABILITÉ DE L'ENVIRONNEMENT

RÉSUMÉ. Les processus individuels de traitement de la peau au stade du prétannage produisent de grands volumes de déchets solides et d'eaux usées, qui représentent la principale source de pollution environnementale caractérisée par la demande chimique en oxygène (DCO), la demande biologique en oxygène (DBO), les solides dissous totaux (SDT), les total des solides en suspension (TSS), le chrome (III) et les composés phénoliques à pH élevé, à forte odeur et de couleur marron foncé. Les eaux usées très polluantes contenant des matières organique, provenant de l'industrie du cuir, sont générées par les processus antérieurs au tannage. Dans le processus de prétannage classique, on utilise des produits chimiques représentant 50 à $60 \%$ de la quantité de pollution et des effluents alcalins avec une toxicité de 70 à $80 \%$. Dans notre étude, la modélisation des meilleures pratiques et des changements de processus respectueux de l'environnement ont été les objectifs en raison de la réduction de la pollution générée par les effluents de l'industrie du cuir. Les processus de trempage, d'immunisation et de pelanage ont été réalisés avec des additifs chimiques réducteurs et tensioactifs, des auxiliaires d'ouverture de fibres, des produits chimiques à base d'enzymes et assistés par enzymes, en utilisant une recette écologique. Les études ont été menées dans le Leather Park Bursa, en Turquie. Les résultats ont révélé les avantages du gain de temps, de la rentabilité et de la charge de pollution minimale par rapport au processus conventionnel. De plus, le procédé conçu utilise une plus petite quantité de produits chimiques alcalins et d'eau, permet d'obtenir des peaux en tripe de haute qualité, à fleur ouverte, et donne un rendement de 50 à $55 \%$ de peaux en croûte d'une épaisseur de 2,2-2,4 $\mathrm{mm}$. MOTS CLÉS : cuir, pelanage, eaux usées, environnement, durabilité

\footnotetext{
* Correspondence to: Ersin ONEM, Ege University, Faculty of Engineering, Department of Leather Engineering, 35100, Izmir, Turkiye, Tel.: +90 232311 2644, e-mail: ersin.onem@ege.edu.tr
} 


\section{INTRODUCTION}

The tanning industry worldwide produces a significant amount of solid wastes and effluents, environmental concerns about discharge and escalating landfill costs are becoming increasingly serious problems for industry and management alternatives regarding overall consideration based on multi-spot. Due to the fact that 1 ton of wet salted hides yields in $200 \mathrm{~kg}$ of finished leather and requires $15-50 \mathrm{~m}^{3}$ water consumption along with the usage of 500 $\mathrm{kg}$ process chemicals, the production emanating $800 \mathrm{~kg}$ wastes including tanned solid wastes of $250 \mathrm{~kg}$, non-tanned wastes of $350 \mathrm{~kg}$ and discharged wastes of $200 \mathrm{~kg}$ in the process water of 15-50 $\mathrm{m}^{3}$ [1].

Due to both environmental concerns caused by the industrial individuality and pollution emanating inherently from the material itself structure and also global stringencies in many places all over the world have constrained to relocate the industry to designated leather parks along with the implementation of Common Effluent Treatment Plants (CETPs) [2]. In liaison with the globalization and emerging trade unities and also their impacts, cleaner production was adopted and the industry has been obliged to stand out against the enforcement of stringent regulations.

As we know, the traditional loosening fibers process, leather liming (lime, sodium sulfide, etc.), is operated to achieve the objective of the leather loose fibers by means of decomposing the fiber in the high $\mathrm{pH}$ of the water. This process produces high-pH value of sewage, which is rich in lime, sulfide, biological oxygen demand, chemical oxygen demand, lipidic saponification or emulsion matter, protein, hair degradation products, organic nitrogen, ammonia nitrogen salt, and so on. Especially for the lime used in this procedure, its large dosage contributes hugely to a great deal of solid sludge.

To bring the tanning industry more in line with present environmental thinking, various methods have been devised to reduce impacts. Big efforts have been made to reduce pollution load, decrease process time and get improvement in the product quality $[3,4]$. Other methods of cleaner process in leather-making are tested synchronously $[5,6]$. Efforts from researchers and scholars are insistently carried out to reduce leather pollution [7-14]. However, serious betterments could not be achieved until now.

Bursa Specialized Leather and Mixed Organized Industrial Zone called as BIDOSB in abbreviation is the Pioneer Leather Park located in southern Marmara region in Turkey (Figure 1). In the region 200 tons of hides are processed daily, that is one fifth of Turkey production annually. Once in the first time of relocation it was designed just for resettlement of the tanneries in Bursa Province, but later as a consequence of high logistic prices of Tuzla Leather Park, majority of the biggest tanneries in Turkey moved their facilities in this region. However, the infrastructure and common treatment plant capacity which was designed by taking into consideration of the first facility layouts remained incapable of the treatment of newly need-based capacity. Due to full capacity running of the several biggest tanneries which process raw hides to wet-blue, the increasing flow rates and changing the regime of the effluent gave rise to decrease the efficiency of infrastructure and facilities and required to take measures for adequate and efficient treatment. For this reason management of CETP practices are of main importance now and prerequisites are to be taken into consideration. There are 5 control points before CETP entree unit and the last adjustment in equalization tank. But above all the cleaner processing attempts, best available techniques and eco compatible interventions were our main goals for now and so sustainable forth. 

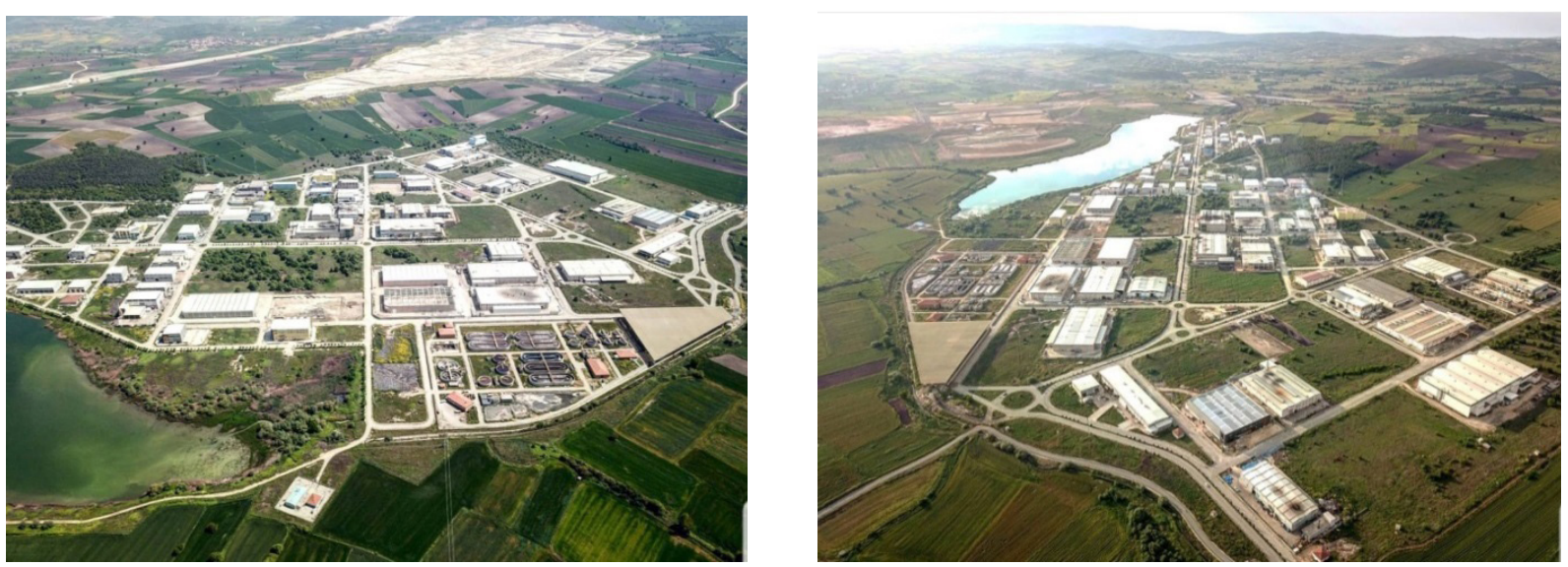

Figure 1. Bursa Leather Park

\section{METHODOLOGY}

Nowadays, as a key sector, leather industry has a new challenge to deal with: to minimize its environmental impacts by evaluating throughout the production process under a new point of view, that is, detecting inefficiencies and discovering that an additional economic benefit can also be achieved by reducing pollution generation. Expensive end-of-pipe treatment and retrospective clean up should be overcome and complemented with pollution prevention measures in order to reduce costs and risks, and gain competitiveness.

There is one practical and reasonable approach for low level waste (LLW) in any industry; that is, waste minimization at source. Minimization is so applicable in the process inline and source reduction practices reduce or eliminate waste generation. So it comprises environmentally sound recycling practices. This minimization at source and internal recycling as priorities leads to product and process redesign, adopt new technologies and good housekeeping.

With this respect, our work was to suggest a set of recommendations to subsidize the practitioners in implementing initiatives promoting environmentally friendly measures to be adopted. It includes environmentally viable methods to practice in-line and to modify it according to the analytical results. We focused on beamhouse processes and traced back to the process parameters considering the analyses.

A process recipe was set by some preliminary trials and after some modification it was incorporated into a guideline for any private company to use their own chemicals. According to the properties of chemical used and treatments, the variables such as water, liming auxiliary, reductive surfactant, enzyme (keratinase), sodium hydrosulphide, sodium sulphide and lime were studied. The variables applied in the designed recipe, their impacts and the remarks are seen in Table 1. Process guidelines for both conventional and eco-recipe were provided in Table 2 and Table 3. Soaking, immunization and liming processes were applied in one-bath with eco-friendly way to reduce the process water. 
Table 1: Variables, impacts and remarks of the process

\begin{tabular}{|c|c|c|}
\hline Variables & Impacts & Cautions \\
\hline Water & $\begin{array}{l}\text { Continuous phase in dispersion, appropriate } \\
\text { mechanical action }\end{array}$ & $\begin{array}{l}\text { Volume of pollution load, wrinkles along with } \\
\text { increasing mechanical action. }\end{array}$ \\
\hline Liming Auxiliaries & $\begin{array}{l}\text { Good dispersion of primary lime and other } \\
\text { particles }\end{array}$ & $\begin{array}{l}\text { Good and appropriate swelling, clean-up of } \\
\text { soluble materials and epidermal deposits. }\end{array}$ \\
\hline Reductive surfactants & $\begin{array}{l}\text { Improves loosening of epidermis, scud and } \\
\text { the removal of natural pigment. }\end{array}$ & $\begin{array}{l}\text { Allows a significant reduction of the sulfide } \\
\text { and reduces pollution and alkalinity. }\end{array}$ \\
\hline Keratinase & $\begin{array}{l}\text { Degradation of soft keratin and loosening of } \\
\text { hair root }\end{array}$ & Low COD, less sludge, reduced nitrogen. \\
\hline Sodium hydrosulphide & $\begin{array}{l}\text { Milder effect on break-down of disulfide } \\
\text { bonds (S-S) of cystine causing keratin } \\
\text { degradation }\end{array}$ & $\begin{array}{l}\text { Increases the } \mathrm{pH} \text {, alkalinity. Total destruction } \\
\text { of keratin and thereby increased sulphide and } \\
\text { soluble colloids in effluent. }\end{array}$ \\
\hline Sodium sulphide & $\begin{array}{l}\text { Stronger break-down of disulfide } \\
\text { bonds (S-S) of cystine causing keratin } \\
\text { degradation }\end{array}$ & $\begin{array}{l}\text { Increases the } \mathrm{pH} \text {, alkalinity with high swelling } \\
\text { and veinness. Increased sulphide and soluble } \\
\text { colloids in effluent. }\end{array}$ \\
\hline Calcium hydroxide & Opening-up and Collagen hydrolysis & $\begin{array}{l}\text { Relaxed leathers with loosened grain, necks' } \\
\text { and shanks' wrinkles. } \\
\text { Collagen fibers become finer and shorter, } \\
\text { which allows obtaining emptier leathers. }\end{array}$ \\
\hline
\end{tabular}

Table 2: Basic recipe for soaking and liming process

\begin{tabular}{|c|c|c|c|c|c|c|}
\hline Process & Chemicals & Percentage (\%) & Temp $\left({ }^{\circ} \mathrm{C}\right)$ & Run (Min.) & Stop (Min.) & Remarks \\
\hline \multirow[t]{5}{*}{ Pre-soaking } & Water & 300 & 26 & & & $2 \mathrm{rpm}$ \\
\hline & Soda ash & 0.2 & & & & \\
\hline & Bactericide & 0.1 & & & & \\
\hline & Surfactant & 0.2 & & 30 & 30 & Dirt and dung \\
\hline & & & & 30 & 40 & removal \\
\hline \multirow[t]{7}{*}{ Soaking } & Water & 200 & 26 & & & $1.5-2 \mathrm{rpm}$ \\
\hline & Surfactant & 0.8 & & 30 & 30 & \\
\hline & & & & 30 & 30 & \\
\hline & & & & 30 & 30 & \\
\hline & & & & 120 & & \\
\hline & Bactericide & 0.1 & & 60 & 40 & Drain \\
\hline & Water & 200 & 26 & 60 & & Drain \\
\hline \multirow[t]{5}{*}{ Liming } & Water & 200 & 26 & & & \\
\hline & Sodium sulphide & 1.5 & & & & \\
\hline & Lime & 6.0 & & 30 & & \\
\hline & Sodium sulphide & 1.5 & & 30 & & $\begin{array}{l}2 \mathrm{~min} / 60 \mathrm{~min} \\
\mathrm{~T}: 14 \text { hour }\end{array}$ \\
\hline & Water & 10 & $26-27$ & 60 & & $\begin{array}{l}\text { Hairs and } \\
\text { epidermal } \\
\text { residuals } \\
\text { removed }\end{array}$ \\
\hline
\end{tabular}


Table 3: Eco-friendly designed recipe

\begin{tabular}{|c|c|c|c|c|c|c|}
\hline Process & Chemicals & Percentage (\%) & Temp $\left({ }^{\circ} \mathrm{C}\right)$ & Run (Min.) & Stop (Min.) & Remarks \\
\hline \multirow[t]{4}{*}{ Pre-soaking } & Water & 100 & 26 & & & $1.5-2 \mathrm{rpm}$ \\
\hline & Soda ash & 0.2 & & & & \\
\hline & Bactericide & 0.1 & & & & \\
\hline & Surfactant & 0.1 & & $\begin{array}{l}20 \\
30\end{array}$ & $\begin{array}{l}30 \\
40\end{array}$ & $\begin{array}{l}\text { Dirt and dung } \\
\text { removal }\end{array}$ \\
\hline \multirow[t]{6}{*}{ Soaking } & Water & 100 & 26 & & & $1.5-2 \mathrm{rpm}$ \\
\hline & Surfactant & 0.5 & & & & \\
\hline & $\begin{array}{l}\text { Degreasing agent } \\
\text { (Non-ionic emulsifier) }\end{array}$ & 0.2 & & $\begin{array}{l}30 \\
180\end{array}$ & 40 & \\
\hline & Soaking enzyme & 0.3 & & 20 & & \\
\hline & Reductive auxiliary & $0.3-0.4$ & & 60 & & \\
\hline & Bactericide & 0.1 & & 60 & 40 & $\begin{array}{l}\text { Entirely } \\
\text { soaked }\end{array}$ \\
\hline \multirow[t]{4}{*}{ Immunization } & Soda ash & $0.3-04$ & & 60 & & \\
\hline & Sodium sulphide & 0.1 & & & & \\
\hline & Reductive auxiliary & $0.15-0.20$ & 26.5 & 60 & & $\begin{array}{l}\text { Loosening of } \\
\text { pulp. } 4 \mathrm{Be}^{\prime}, \\
\mathrm{pH}: 9.5\end{array}$ \\
\hline & & & & & & $\begin{array}{l}\text { If necessary } \\
\text { drain well } \\
\text { and add } 50 \% \\
\text { water }\end{array}$ \\
\hline \multirow[t]{11}{*}{ Liming } & Liming auxiliary & $0.7-1$ & $26-27$ & & & \\
\hline & Enzyme (Keratinase) & 0.4 & & & & \\
\hline & Non-ionic emulsifier & $0.3-0.4$ & & 60 & & \\
\hline & Lime & 1.0 & & & & \\
\hline & Sodium hydrosulphide & 1 & & 90 & & \\
\hline & Lime & 0.5 & & & & \\
\hline & Sodium sulphide & 0.4 & & 60 & 60 & \\
\hline & Lime & 0.5 & & & & \\
\hline & Sodium sulphide & 0.4 & & & & \\
\hline & Lime & 0.5 & & 40 & 60 & $\begin{array}{l}5 \mathrm{~min} / 30 \mathrm{~min} \\
\mathrm{~T}: 12 \text { hour }\end{array}$ \\
\hline & Water & 40 & & 60 & & $\begin{array}{l}\text { Hairs and } \\
\text { epidermal } \\
\text { residuals } \\
\text { removed }\end{array}$ \\
\hline
\end{tabular}

Studies were performed in the factories which are active in Bursa Leather Park. After conventional and new designed processes, analyses of electrical conductivity according to SM 2510 B standard process, total suspended solids (TSS) to TS EN 872, total dissolved solids (TDS) to SM $2540 \mathrm{C}$, chemical oxygen demand (COD) to SM 5220 B, oil \& grease to SM 5220 $C$ and total Kjeldahl nitrogen (TKN) to SM
4500 Norg B were applied in the wastewaters. Moreover, total sulphide and total chromium analyses were carried out in equalization tank with SM 4500-S-2 D and ISO 11885 methods, respectively. Thus, how pollution load changes with the new production way in the industrial zone and performance assessment of green practices in liming process was evaluated. 


\section{RESULTS AND DISCUSSION}

Water is crucial for life and also used in many industrial processes and the industrial sectors take up an average of $22 \%$ of the globally used water. With regard to the increasing concern with environment and sustainability, it is vital that natural sources should be inherited to next generations. Leather industry is one of the primary sector with a high water usage and such excessive usage, resulting from adoption of traditional processing methods and equipments lead to acute water availability and effluent treatment problems [15].

Leather industry worldwide is recognized as a serious environmental threat due to its own pollutive potential including salinity, organic load (chemical oxygen load or demand, biological oxygen demand), inorganic matter, dissolved, suspended solids, ammonia, total kjeldahl nitrogen (TKN), specific pollutants (sulfide, chromium, chloride, sodium and other salt residues) and heavy metals etc. [16]. A part of the leather processing, solid and gaseous wastes are also discharged into the environment. Among the numerous phases of the tanning process, the beamhouse phase represents $83 \%$ of the $\mathrm{BOD}_{5}$, $73 \%$ of the COD, $60 \%$ of the suspended solids, $68 \%$ of the salinity and $76 \%$ of the total polluting charge produced during the manufacturing process of hides. Besides, in the beamhouse, the traditional unhairing process with sodium sulfide and lime is responsible for most pollution. Consequently, the development of an alternative unhairing process, characterized by a lower environmental impact than the traditional, represents a priority in the leather research field.

Liming involves the use of alkaline medium (e.g. lime) to condition raw hides and skins. The aim is to remove the hair, flesh and splitting up of the fibre bundles by chemical and physical means $[17,18]$. The process not only removes epidermal structures; but also brings about the removal of non-structural protein of the pelts by a certain swelling and plumping. As the term implies leather is made or marred during liming. So, the process modifies the skin fibre for subsequent penetration of other processing chemicals such as tannins and other leather building auxiliaries. Hence; since 1880s neither the process was changed nor improved because of refraining from low quality characteristics. However, the use of this chemical combination generates large volumes of waste that constitutes major source of pollutants amounting to more than $65-70 \%$ in combined tannery effluent $[19,20]$. Its effluents composed of both organic, inorganic matter and containing metals make the treatment very complicated and expensive. If this wastewater is not properly treated before discharge it may adversely affect the ecology of agricultural land.

Parameters and properties of the conventional process wastewater before the betterment studies were provided in Table 4 . Table 4 also shows the analytical results after betterment studies, betterment ratios were given compared to the conventional process.

Table 4: Parameters and analytical results from the process wastewaters and betterments

\begin{tabular}{lccc}
\hline \multicolumn{1}{c}{ Parameters } & $\begin{array}{c}\text { Conventional } \\
\text { process results }\end{array}$ & $\begin{array}{c}\text { Results after } \\
\text { betterment studies }\end{array}$ & Betterment ratio \\
\hline Conductivity (mS/cm) & 73 & 59 & $19.17 \%$ \\
TSS (mg/L) & 31,520 & 24,660 & $21.76 \%$ \\
TDS (mg/L) & 69,768 & 64,960 & $6.89 \%$ \\
COD (mg/L) & 58,984 & 38,976 & $33.92 \%$ \\
Oil/Grease (mg/L) & 650 & 565 & $13.07 \%$ \\
TKN (mg/L) & 3,417 & 2,927 & $14.34 \%$ \\
\hline
\end{tabular}

Indicated results from equalization tank before and after betterment studies were provided in Table 5. Results after betterment studies and conventional process were compared. Betterment ratios were calculated according to the differences of the values between conventional process and eco-friendly designed process. 
Table 5: Indicated results from equalization tank before and after betterment studies

\begin{tabular}{lcccc}
\hline Parameters & $\begin{array}{c}\text { Conventional } \\
\text { process results }\end{array}$ & $\begin{array}{c}\text { Results after } \\
\text { betterment studies }\end{array}$ & Reference values & Betterment \\
\hline Conductivity (mS/cm) & 11.71 & 8.16 & 8 & $30.32 \%$ \\
TSS (mg/L) & 2,867 & 1,950 & 3,000 & $31.98 \%$ \\
COD (mg/L) & 4,998 & 3,356 & 5,500 & $48.92 \%$ \\
Oil/Grease (mg/L) & 320 & 254 & 668 & $20.63 \%$ \\
TKN (mg/L) & 389 & 358 & 120 & $7.97 \%$ \\
Sulphide (mg/L) & 110 & 82 & 95 & $25.45 \%$ \\
Total chromium (mg/L) & 138 & 77 & 100 & $44.2 \%$ \\
\hline
\end{tabular}

Liming has utmost sensitivity. It is the key process of the leather production and directly affects the final leather quality. In case small changes in the process are not applied in a proper way, next processes are not carried out as they should be and leather can be destroyed. That is why, the industrial players never give up from the conventional ways for this process. Different applications as less water utilization, keratinase applications, minimum chemical dosages etc. make the process highly risky. In our study, this vital conditions have been taken into consideration and variables have been conscientiously selected with the sensitive works.

Results showed the considerable betterments after our eco-designed recipe. The highest enhancement in process wastewaters and equalization tank was provided on COD levels. Conventional process had 58,984 mg/L and results after eco-friendly applications were $38,976 \mathrm{mg} / \mathrm{L}$ in COD with $33.92 \%$ betterment ratio. This ratio was $48.92 \%$ in equalization tank with $4,998 \mathrm{mg} / \mathrm{L}$ and $3,356 \mathrm{mg} / \mathrm{L}$ COD levels, respectively. Table 5 indicated that all the parameters related to pollution load were reduced under the reference values. TSS, TKN, sulphide, oil/grease and total chromium results showed the satisfactory betterment grades with the acceptable distances to the limitations. Only conductivity was over the reference value, but it was also decreased from $11.71 \mathrm{mS} / \mathrm{cm}$ to 8.16 $\mathrm{mS} / \mathrm{cm}$.

In addition, not only these parameters decreased but also the wastewater treatment charge and the transport charge for tannery sludge was also reduced. Moreover, tons of wastewater and pollution load will be minimized in the industrial zones by less usage of process water and less dosage chemicals via eco-designed recipe. Filtration application was not applied in our study, but in case of this application as well, betterment attained would be much higher than the current case. Our studies are going on the filtration applications for the process and channel waters.

\section{CONCLUSIONS}

Tanning industry produces a significant amount of solid wastes and effluents. As a well-known fact, while removing undesired substances and ingredients out of the structure and isolation in leather processing and thereby; facilitating the reactions between chemicals and skin/hide protein, its pollution load is final and highlighted agenda which needs to be overcome by introducing sustainable cleaner technologies. Novel and environmentally friendly techniques and processing ways for leather industry were highly demanded and forced by the governments after strict environmental stipulation norms. Our study provided the minimized pollution load for leather industry by creating eco-friendly designed process. Cleaner processing attempts, available techniques and eco-compatible interventions will generate the sustainable future for the industry.

\section{REFERENCES}

1. Yang, Q., Qin, S., Chen, J., Ni, W., Xu, Q., Supercritical carbon dioxide-assisted loosening preparation of dry leather, J Appl Polym Sci, 2009, 113, 4015-4022, https://doi. org/10.1002/app.30476.

2. Karafakioglu, Y., Gene, O., Biochemical examination of waste water caused by Usak 
leather facilities, Fresen Environ Bull, 2012, 26, 704-710.

3. Sivakumar, V., Rao, P.G., Studies on the use of power ultrasound in leather dyeing, Ultrason Sonochem, 2003, 10, 85-94, https://doi. org/10.1016/S1350-4177(02)00148-7.

4. Sivakumar, V., Chandrasekaran, F., Swaminathan, G., Rao, P.G., Towards cleaner degreasing method in industries: Ultrasound-assisted aqueous degreasing process in leather making, J Clean Prod, 2009, 17, 101-104, https://doi.org/10.1016/j. jclepro.2008.02.012.

5. Sreeram, K.J., Ramasami, T., Sustaining tanning process through conservation, recovery and better utilization of chromium, Resour Conserv Recy, 2003, 38, 185-212, https://doi. org/10.1016/S0921-3449(02)00151-9.

6. Santos, L.M., Gutteres, M., Reusing of a hide waste for leather fatliquoring, I Clean Prod, 2007, 15, 12-16, https://doi.org/10.1016/j. jclepro.2006.01.025.

7. Li, S., Li, J., Yi, J., Shan, Z., Cleaner beamhouse process trial on cattle sofa leather, $J$ Clean Prod, 2010, 18, 471-477, https://doi. org/10.1016/j.jclepro.2009.11.010.

8. Mariliz, G., Patrice, M.A., Joana, B.P., Jorge, O.T., Water reuse in tannery beamhouse process, $J$ Clean Prod, 2010, 18, 1545-1552, https://doi. org/10.1016/j.jclepro.2010.06.017.

9. Hu, J., Xiao, Z., Zhou, R., Deng, W., Wang, M., Ma, S., Ecological utilization of leather tannery waste with circular economy model, J Clean Prod, 2011, 19, 221-228, https://doi. org/10.1016/j.jclepro.2010.09.018.

10. Almeida, C.M.V.B., Bonilla, S.H., Giannetti, B.F., Huisingh, D., Cleaner production initiatives and challenges for a sustainable world: An introduction to this special volume, J Clean Prod, 2013, 47, 1-10, https://doi. org/10.1016/j.jclepro.2013.03.010.

11. Dettmer, A., Cavalli, E., Ayub, M.A.Z., Gutterres, M., Environmentally friendly hide unhairing: Enzymatic hide processing for the replacement of sodium sulfide and deliming, J Clean Prod, 2013, 47, 11-18, https://doi. org/10.1016/j.jclepro.2012.04.024.

12. Lofrano, G., Meric, S., Zengin, G.E., Orhon, D., Chemical and biological treatment technologies for leather tannery chemicals and wastewaters: A review, Sci Total Environ,
2013, 461-462, 265-281, https://doi. org/10.1016/j.scitotenv.2013.05.004.

13. Saravanan, P., Renitha, T.S., Gowthaman, M.K., Kamini, N.R., Understanding the chemical free enzyme based cleaner unhairing process in leather manufacturing, J Clean Prod, 2014, 79, 258-264, https://doi. org/10.1016/j.jclepro.2014.05.022.

14. Deng, W., Chen, D., Huang, M., Hu, J., Chen, L., Carbon dioxide deliming in leather production: A literature review, I Clean Prod, 2015, 87, 26-38, https://doi.org/10.1016/j. jclepro.2014.09.066.

15. Sundar, V.J., Ramesh, R., Rao, P.S., Saravanan, P., Sridharnath, B., Muralidharan, C., Water management in leather industry, J Sci Ind Res India, 2001, 60, 443-450.

16. Chowdhury, M., Mostafa, M.G., Biswas, T.K., Saha, A.K., Treatment of leather industrial effluents by filtration and coagulation processes, Water Resources and Industry, 2013, 3, 11-22, https://doi.org/10.1016/j. wri.2013.05.002.

17. Mwinyihija, M., Ecotoxicological Diagnosis in the Tanning Industry, Main Pollutants and Environmental Impacts of the Tanning Industry, Springer Science+Business Media, 2010, 140 p, https://doi.org/10.1007/978-14419-6266-9.

18. Mwinyihija, M., Pollution control and remediation of the tanning effluent, The Open Environmental Pollution \& Toxicology Journal, 2012, 3, 55-64, https://doi.org/10.2 174/1876397901203010055.

19. Leafe, M.K., Leather Technologists Pocket Book, Society of Leather Technologists and Chemists, 1999, $405 \mathrm{p}$.

20. United Nations Industrial Development Organization (UNIDO), Regional Programme for Pollution Control in the Tanning Industry in South-East Asia, The Scope For Decreasing Pollution Load in Leather Processing, 2000, $34 \mathrm{p}$.

(C) 2019 by the author(s). Published by INCDTPICPI, Bucharest, RO. This is an open access article distributed under the terms and conditions of the Creative Commons Attribution license (http:// creativecommons.org/licenses/by/4.0/). 